\title{
Identification and validation of coaching skill components among faculty members of universities
}

\author{
Mohammad Mohammadisadr ${ }^{1}$ \\ Seyed Ali Siadat ${ }^{1}$ \\ Reza Hoveida ${ }^{1}$
}

\section{Abstract}

Human resource development is an important factor for improving organizations. Universities as educational organizations need high-quality human resources. In this sense, coaching can be introduced as a new approach for professional development in higher education. Faculty members of universities can act as coaches to help the students and colleagues develop and thrive. Coaches with high levels of skills can be very influential. Not all individuals in higher education capacities have the necessary skills to become coaches. Hence, coaching skills should be specified so as to select high-quality leaders. The aim of the present study was to identify and validate coaching skills at universities. The population of the study consisted of students of a medical sciences university in Isfahan and the University of Isfahan. Research methods were both qualitative and quantitative. For the qualitative part, participants who were experts in human resource development and education were chosen. For the quantitative assessment, participants were selected among faculty members at both universities. Results indicated that being a successful coach requires at least eight specific skills. These eight skills should serve as the basis for selecting coaches in higher education.

\section{Keywords}

Coaching - Professional development - Coaching skills - Higher education - E-learning - Human resources.

1 - University of Isfahan. Isfahan. Iran.

Contacts: mohammadisadr@gmail.com; s.a.siadat@edu.ui.ac.ir; r.hoveida@edu.ui.ac.ir 


\section{Identificação e validação dos componentes de habilidades de coaching entre professores universitários}

\section{Resumo}

O desenvolvimento de recursos humanos é fator importante no aprimoramento das organizações. As universidades enquanto organizações educacionais necessitam de recursos humanos de alta qualidade. Nesta perspectiva, pode-se inserir o coaching como nova abordagem para o desenvolvimento profissional no ensino superior. Professores universitários podem atuar como coaches de modo a auxiliar alunos e colegas a se desenvolver e prosperar. Estes coaches com elevados niveis de habilidades podem exercer grande influência. Nem todos os indivíduos em cargos universitários dispõem das habilidades necessárias para se tornarem coaches. Por isso, as habilidades para tal devem ser especificadas de modo a se selecionar líderes de alta qualidade. $O$ objetivo do presente estudo foi identificar e validar as habilidades de coaching no ensino superior. A população estudada era composta por estudantes do curso de medicina de uma faculdade em Isfahan e da Universidade de Isfahan. Os métodos de pesquisa utilizados foram tanto quantitativos quanto qualitativos. $\mathrm{Na}$ parte qualitativa, os participantes foram escolhidos aqueles especialistas em desenvolvimento de recursos humanos e educação. Para a avaliação quantitativa, os participantes foram selecionados entre os membros do corpo docente das duas universidades. Os resultados mostraram que os coaches bem-sucedidos cumpriam com ao menos oito habilidades especificas. Tais habilidades deveriam ser utilizadas como base para a escolha de coaches na educação superior.

\section{Palavras-chave}

Coaching - Desenvolvimento profissional - Habilidades de coaching - Educação superior - Ensino a distância - Recursos humanos.

\section{Introduction}

Higher education is transmuting itself in an attempt to adjoin the multiple requirements that society has inflicted on it. Educators, therefore, are being imposed to assist in devising the future rather than merely pass on knowledge that will only repeat the past. The educator's role is to prepare learning opportunities that strategically make grow the skills students need to work successfully in their professions (BRANCATO, 2003). As higher education efforts are made to tackle these many disputes, faculty members are finding it progressively difficult to hold abreast not just of specific knowledge but also teaching inventions. Hence, development plans have been inducted to help faculty reflect 
on their teaching and make stronger connections between instructing strategies and their disciplinary knowledge and skills (KLENOWSKI, ASKEW; CARNELL, 2006).

In a higher education system, one of the basic factors having significant roles in improving the quality of its outputs is faculty members, in that they not only have the duty of helping students construct knowledge, but also assist them in creating visions and educating employable skills within the framework of aims of the higher education system (WHITTEN, 2016). This issue is particularly crucial because of the changes in higher education in the $21^{\text {st }}$ century and the necessity to increase coordination of higher education with the world of industry and business as well as the widespread use of Information Technology (IT). Moreover, professional development of faculty members is an important factor in promoting quality of higher education (NICHOLLS, 2014). To be successful in three functional domains of education, research, and servicing societies, universities should pay attention to the capabilities of faculty members. Reinforcing those capabilities can be carried out via their professional development and growth.

Blackmore and Castley (2006) defined capability development as "all of the provision and processes that are designed to enhance the efficiency and effectiveness of individuals, activities and the organization" (p. 16). Blackmore (2009) proposed five types of development in higher education institutions, including: 1- educational development, 2- staff development, 3- academic development, 4- faculty development and, 5- organizational development.

Higher education institutions are required to develop their human resources because the ultimate objective of higher education is currently to support the development of standards for professional development, that is, to reinforce learning and teaching in higher education (KING, 2009). Therefore, professional development is considered as one of the most important issues in higher education that needs to be investigated.

Different studies have been conducted on coaching in higher education around the world (BLACKMORE, 2009; BRANCATO, 2003; KING, 2009; KLENOWSKI; ASKEW; CARNELL, 2006; MCALEESE, 1979; RIENTIES; BROUWER; LYGO-BAKER, 2013; ROXA; MÅRTENSSON, 2008). Also, studies in Iran (KARIMI et al., 2015; HEJAZI; ROSTAMI, 2010; NOURSHAHI; SAMIEI, 2011; AHANCHIAN; KARAMI; AHMAD ABADI, 2014) indicated that the issue of professional development of faculty members has not been yet considered appropriately; therefore, it seems necessary to identify the needs of professional development of faculty members, and plans are required in order to do so. One of those plans used to develop sophisticated and experienced individuals is coaching (IVES, 2008).

Coaching is an approach for empowering and developing individuals both individually and in group. This approach enables individuals to create positive changes in themselves. Coaching is defined as a process which supports individuals in making decisions more consciously and doing new activities. Coaching assists individuals to determine their own internal resources and enhance them from their current status up to more favorable and ideal statuses. Coaching is a form of professional development connecting individuals' learning to their practices. This type of training has colleagues' feedbacks and supports. Coaching is an integral part of the process of improving individuals' performances because this type of training tries to compose effective professional development based on the 
individual's needs (POLLY, MRAZ; ALGOZZINE, 2013). Therefore, selecting coaches in universities and scientific institutes is an important process. In addition, coaches who can act and perform effectively play a significant role. Coaching has its own features and properties. If they are selected appropriately, coaching can achieve its purposes. According to Wilson and Gisalson (2009), coaching has different skills, some of which are considered as basic coaching skills: listening, questioning and answering, feed-backing and sharing. Conner et al. (2008) found out that coaches who have the skill of decision making are more successful in their performances. Coaches who enjoy better analysis regarding communication supports with others can more effectively achieve their purposes (MARSH; SLOAN MCCOMBS; MARTORELL, 2010). Fullen and Knight (2011) refer to this issue as those coaches who can create better workplaces through cooperation and development of some activities for providing some conditions in which individuals have cooperation with each other and are more effective in training.

\section{Coaching performance in the literature}

Coaching began as a strategy for improving quality of individuals' performance in organizations in the 1980's. First, the initial aim of coaching was to change traditional professional development. Upon the evaluation of staff development in a number of organizations, it was found that workers applied what they had been presented in trainings. Recent studies indicated that individuals with coaches have learned new skills and working strategies, but those without such an experience have advanced better and more appropriately (CAMPBELL; MALKUS, 2011). Coaches act as a resource in educational organizations as management supporters and trainers. They try to improve individuals' activities and their ultimate aim is to influence achievements of individuals and their organizations. According to Schroeder and Friesen (2007), coaches play roles and take responsibilities as supporters of organizations, educational experts, experts of planning, professional developers, analyzers, agents of change and providers of resources. With these descriptions, coaching has multiple dimensions, but its key responsibilities is to increase individuals' quality for affecting their achievements. Individuals who are considered as coaches in organizations should have specific skills. According to Houston (2015), the staff believe that training coaches create opportunities for participating in activities, sharing knowledge, designing and reflecting activities. It is via participation and coaching that individuals will be able to analyze the data obtained from their job design and working observations. Othman and Yee (2015) indicated that coaching strategies are highly effective in improving the process of teaching, learning, and monitoring postdoctoral students. Their results also indicated that coaching strategies act successfully in improving the four skills of Action Research. In most studies, the focus is on coaching processes. In other words, the effect of coaching processes on individuals' development is investigated in those studies. However, some other studies have investigated coaching skills as well (HOWLEY et al., 2014; KOWAL; STEINER, 2007; MCLEAN et al., 2005). 


\section{Coaching and learning}

Everyone can learn in different ways. Universities are one way of learning which changes references of learners. Technology is an instrument that changed communication so that learning can be used online as e-learning. Research findings showed that e-learning could be illustrated as an effective system for empowerment of employees' individual performance. Universities can use online discussion classes for improving the progress of empowerment (HUR; IM, 2013). Al-Azawei, Parslow and Lundqvist (2016) showed that the use of e-learning in developing countries is at a very early stage. They explained that most public universities cannot use e-learning because they still lack enough knowledge and skills to do it correctly. Iran is a developing country too that faces obstacles in communication and technology. Thus, e-learning can be used as a limited scope because there is not sufficient trust in using the internet for educational purposes. People who volunteer to take part in electronic education are those who cannot succeed in entering public universities. Therefore, developing countries, including Iran, do not have enough capacity to develop e-learning (RABIEE; NAZARIAN; GHARIBSHAEYAN, 2013).

In the communication and technology world, everything can change rapidly and coaching process needs to change as well. Coaching is considered to help and direct the development of skills such as time management, leadership and communication (ROSSETT; MARIN0, 2005). Coaching can also be used to obtain learning from training courses by helping the coachee aim and follow through on the necessary actions. This sort of coaching is suitable for online training courses. E-coaching can be defined as any form of coaching that utilizes electronic media (FRAZEE, 2008). The one reason for this preference is that coaches can talk to other coaches and get a feel for motivation and mood level. Likewise, coaching counts on different instruments such as email, online discussion groups, appropriate online coaching platform and automated self-coaching programs (AVERWEG, 2010). E-coaching as well as e-learning has barriers in developing countries. Thus, using e-coaching requires basic infrastructure, including technology and changing attitudes of people and decision makers. Hence, this study prefers to investigate coaching skills for establishing a coaching mechanism that can use e-coaching in the future.

Considering the literature, we observe that none of the studies directly refer to coaching skills. Also, findings of literature- review in recent decades, related to faculty members in Iran (KARIMI et al., 2015; HEJAZI; ROSTAMI, 2010; NOURSHAHI; SAMIEI, 2011; AHANCHIAN; KARAMI; ABADI, 2014) indicate that the issue of professional development of faculty members has not been considered appropriate yet; therefore, it seems necessary that needs of professional development of faculty members should be addressed and some plans should be developed for realizing it.

Having a series of skills for doing each kind of activity, particularly in training, seems necessary. So it is better that the individuals who are selected as Coaches in universities and higher education institutions should have skills in order to be more efficient in the training sector. Therefore, the aim of the present study is to find some coaching skills which play main and fundamental roles among other skills. In addition, the individuals 
selected as Coaches should have those skills, or if they are prepared for taking role in this regard, they should learn a series of those basic skills. (IVES, 2008).

\section{Research objectives}

The present study aims to

1. Identify coaching skills from the viewpoints of faculty members of universities and experts in human resources development and management; and

2. Validate important coaching skills from the viewpoints of faculty members of universities and experts in human resources development and management.

\section{Methodology}

With regard to the nature, subject, and aims of the study, the research method is analytical-inferential. In addition, it uses viewpoints and ideas of experts of human resources development and management; therefore, the research is also developmental. To collect data and present the research model based on the research objective, the bottomup competency model (BYHAM; MOYER, 2005) was employed. This approach is confirmed by a lot of experts and researchers. With regard to this method, first of all features and competencies of coaching were extracted from the literature. Then, interviews were conducted with experts aiming to assess, complete, and collect the related list prepared in the previous stage in order to identify required features and competencies. The population consisted of all experts and theorists of human resources development and management at the Isfahan University of Medicine Sciences and the University of Isfahan in Iran. In this sampling, the researcher analyzed findings concurrently with data collection, and sampling continued until theoretical data saturation was achieved. Thus, 18 experts on human resource development and management participated in interviews (Table1).

Table 1- Sampling qualitative

\begin{tabular}{c|c|c|c|c}
\hline Row & University & Position & Expertise & People \\
\hline 1 & University of Isfahan. Iran & Associate professor & Educational Administration & 4 \\
\hline 2 & University of Isfahan. Iran & Assistant professor & Human Resources Management & 7 \\
\hline 3 & Isfahan University of Medical Sciences & Associate professor & Development of Medical Education & 2 \\
\hline 4 & Isfahan University of Medical Sciences & Professor & Development of Medical Education & 1 \\
\hline 5 & Isfahan University of Medical Sciences & Assistant professor & Development of Medical Education & 4 \\
\hline
\end{tabular}

Source: Research data.

During stages 1 and 2 (review of literature and interviewing experts) and in order to integrate them mutually, a list of features and competencies of educational coaching was prepared. As a result, after surveying experts on human resources development and management as well as deleting and integrating some competencies, the number of competencies reached 27 items. 
To achieve the final list of features and competencies required by human resources development, an initial list, extracted from ideas of experts and elites of human resources development, should be validated. To this end, a researcher-made questionnaire was used, consisting of 27 items about features and competencies to assess and weigh each feature. Scores ranging from 1 (lowest degree) to 5 (highest degree) of significance were considered (Likert Scale). To determine validity of the questionnaire, content validity was investigated. For that purpose, six experts of human resources development were surveyed. To assess the validity of the data obtained from the questionnaire, first of all 30 participants answered the questionnaire. Its reliability was obtained as 0.89 via Cronbach's alpha. After that, 317 copies of the questionnaire were distributed among faculty members of Isfahan University of Medicine Sciences (200 participants) and University of Isfahan (117 participants). To analyze the data and validate items, Exploratory and Confirmatory factor analysis was employed. For Exploratory factor analysis, Rotated Component Matrix was used because it was necessary to recognize categories and divide them into specific factors. For Confirmatory factor analysis, Structural Equation Modeling (PLS) was used to confirm variables of factors.

\section{Results}

One of the statistical methods for analyzing the information contained in the data collection is the agent or factor analysis. This method is used to determine the most influential variables when the number of variables studied and the relationships between them is unknown (THOMPSON, 2004). There are two types of factor analysis: 1 Exploratory factor analysis and 2 - Confirmatory factor analysis. In the latter, a researcher discovers the underlying structure in a relatively large set of variables and the former is based on the basic default confirmation that any particular subset of the variables associated with the factor (KAISER, 1958). In this study, the first was determined through two sets of variables and the relationship by exploratory factor analysis and then using Confirmatory analysis according to the default created in exploratory factor analysis determines which set of variables is defined by a specific factor. By entering the desired variables in software, initially using of KMO and Bartlett's Test, specifies that the data are suitable for analysis (KAISER, 1958). According to table (1) KMO $=0.868$ then, data are appropriate for analysis as well as test results of Bartlett's test of sphericity was significant $\left\{\chi^{2}(317)=1839.783, p<.05(\right.$ Table 1$\left.)\right\}$.

Table 2 - KMO and Bartlett's Test

\begin{tabular}{cccc}
\multicolumn{3}{c}{ KM0 and Bartlett's Test } & \\
\hline \multicolumn{2}{c}{ Kaiser-Meyer-0lkin Measure of Sampling Adequacy } & .868 \\
\hline \multirow{3}{*}{ Bartlett's Test of Sphericity } & Approx. Chi-Square & 1839.783 \\
\hline & df & Sig. & 276 \\
\hline
\end{tabular}

Source: Research data. 
By the Rotated component matrix, variables are shown in the factors after rotation. Each variable is in a factor whose correlation is significant. In this section, the variables are divided into eight factors which were highly correlated. Then, the variables are named on the base of their relationships (Table 2). Then, a factor is named based on the items and entered in Structural Equation Modeling for conformity factor analysis. The value of the criterion for the suitability of the factor load Coefficient is high 0.4 (HULLAND, 1999). In the second stage of factor analysis, we used confirmatory factor analysis: in this part any question (Variable) relation with factors is determined by factor load Coefficient. All factor load Coefficients that are 0.4 high are approved. On the other hand, variables make factors correct (Figure 1). Accordingly, Factor 1 (named Questioning \& Answering) consisted of three items that the factor load coefficients are 0.655,0.743 and 0.766>0.4 that they are confirmed. Factor 2 (named Listening) included three items that the factor load coefficients are 0.752,0.566 and 0.767>0.4 that are confirmed. Factor 3 (named Assessing Person \& Condition) consisted of four items, their factor load coefficients are $0.693,0.763,0.665$ and $0.723>0.4$ that are confirmed. Factor 4 (named Feedback) consisted of four items that the factor load coefficients are 0.684,0.696,0.648 and 0.730>0.4 and are confirmed. Factor 5 (named Problems Solving) consisted of three items, their factor load coefficients are $0.750,0.684$ and $0.762>0.4$ that are confirmed. Factor 6 (named Flexibility) consisted of four items, their factor load coefficients are 0.698,0.665,0.700 and 0.639>0.4 that are confirmed. Factor 7 (named Emotional Stability) consisted of three items, their factor load coefficients are $0.804,0.680$ and $0.736>0.4$ that are confirmed. Finally, factor 8 (named Coordination) included three items, their factor load coefficients are 0.735,0.686 and $0.713>0.4$ that are confirmed (Figure 1).

The reasonability of the measurement model is evaluated by testing the composite reliability (CR), Cronbach's coefficient alpha, and the average variance extracted (AVE). CR is a measurement of scale reliability. CR can assess the internal consistency of the indicator. In Smart PLS, Composite Reliability can be used to measure reliability (HULLAND, 1999). Some researchers prefer to use Composite Reliability (CR) rather than Cronbach Alpha because the latter is criticized for its lower bound value which underestimates the true reliability. However, CR can be used as an alternative as its CR value is slightly higher than Cronbach Alpha whereby the difference is relatively inconsequential (FORNELL; LARCKER, 1981).

The CR for all the latent variable (LV), which never appears as a dependent variable, also called an exogenous variable (LEXV) (PEDHAZUR; SCHMELKIN, 2013), is shown above as 0.7 (Table 3). Therefore, it is reasonable to use these measurement variables (MVs) to measure the LEXVs, and the internal consistency of the measurement model should be reasonably good.

Cronbach's coefficient alpha, utilized to measure the extent to which the MVs can explain the constructed LVs (FORNELL; LARCKER, 1981) is also a reliability measurement tool. It is generally accepted that if the value of the alpha coefficient is greater than 0.70 , then the constructed measurement model will have both satisfactory reliability and stability (HULLAND, 1999). Therefore, the measurement model constructed in this PLS path model is able meet the reliability requirements (Table 3 ). 
Table 3 - Factor loadings and communalities based on a principal components analysis with Varimax rotation for 27 items for Coaching Skills $(\mathrm{N}=317)$

\begin{tabular}{|c|c|c|c|c|c|c|c|c|}
\hline Variables & Factor1 & Factor2 & Factor3 & Factor4 & Factor5 & Factor6 & Factor7 & Factor8 \\
\hline Q1 & 0.741 & & & & & & & \\
\hline Q2 & 0.695 & & & & & & & \\
\hline Q3 & 0.653 & & & & & & & \\
\hline Q4 & & 0.594 & & & & & & \\
\hline Q5 & & 0.634 & & & & & & \\
\hline Q6 & & 0.715 & & & & & & \\
\hline Q7 & & & 0.642 & & & & & \\
\hline Q8 & & & 0.584 & & & & & \\
\hline Q9 & & & 0.751 & & & & & \\
\hline Q10 & & & 0.724 & & & & & \\
\hline Q11 & & & & 0.716 & & & & \\
\hline Q12 & & & & 0.647 & & & & \\
\hline Q13 & & & & 0.730 & & & & \\
\hline Q14 & & & & 0.574 & & & & \\
\hline Q15 & & & & & 0.638 & & & \\
\hline Q16 & & & & & 0.662 & & & \\
\hline Q17 & & & & & 0.746 & & & \\
\hline Q18 & & & & & & 0.584 & & \\
\hline Q19 & & & & & & 0.593 & & \\
\hline Q20 & & & & & & 0.741 & & \\
\hline Q21 & & & & & & 0.672 & & \\
\hline Q22 & & & & & & & 0.701 & \\
\hline Q23 & & & & & & & 0.667 & \\
\hline Q24 & & & & & & & 0.625 & \\
\hline Q25 & & & & & & & & 0.734 \\
\hline Q26 & & & & & & & & 0.725 \\
\hline Q27 & & & & & & & & 0584 \\
\hline
\end{tabular}

Source: Research data.

The average variance extracted (AVE) measures the discriminate validity between the LVs (HULLAND, 1999). It is generally accepted that the AVE should be at least greater than 0.5. Table 3 shows that the AVE values for the LEXVs are all greater than 0.6, which confirmed that the measurement model had relatively good discriminate validity. 
Figure 1 - Confirmatory factor analysis coefficients

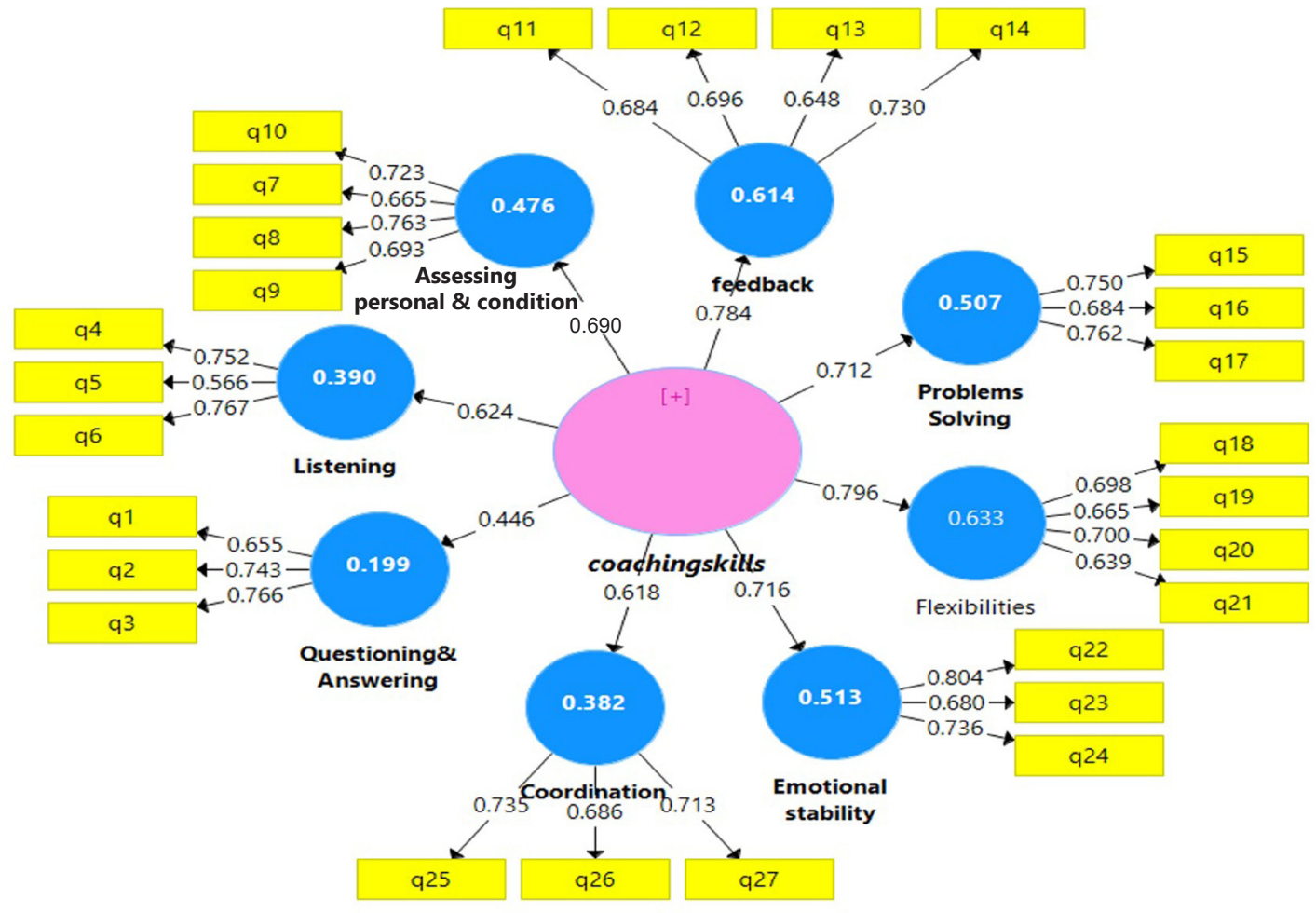

Source: Research data.

Table 4 - Observed Cronbach Alpha, AVE and CR

\begin{tabular}{|c|c|c|c|}
\hline FACTORS & $\begin{array}{l}\text { CRONBACHS ALPHA } \\
(\text { Alpha }>0.7)\end{array}$ & $\begin{array}{c}\text { AVE } \\
(\mathrm{AVE}>0.5)\end{array}$ & $\begin{array}{c}\text { CR } \\
(\text { Alpha }>0.7)\end{array}$ \\
\hline Coordination & 0.715 & 0.617 & 0.731 \\
\hline Emotional stability & 0.791 & 0.691 & 0.741 \\
\hline Flexibilities & 0.704 & 0.703 & 0.743 \\
\hline Listening & 0.885 & 0.782 & 0.761 \\
\hline Problems Solving & 0.768 & 0.662 & 0.862 \\
\hline Questioning \&Answering & 0.848 & 0.748 & 0.751 \\
\hline Assessing person \& Condition & 0.775 & 0.670 & 0.840 \\
\hline Feedback & 0.733 & 0.630 & 0.746 \\
\hline
\end{tabular}

Source: Research data. 
Establishing discriminant validity is crucial for leading latent variable analysis. Fornell and Larcker (1981) also demonstrate a method for assessing the discriminant validity of two or more factors. Here, a researcher compares the AVE of each construct with the shared variance between constructs. If the AVE for each construct is greater than its shared variance with any other construct, discriminant validity is supported. However, given the limitations in data collection and the need for more stringent evaluations of validity, it seems that the Fornell and Larcker (1981) technique represents the best method to apply (FARRELL; RUDD, 2009). Hence, the approach (Fornell-Larcker) is utilized to measure the discriminant validity of this study model. As per Fornell-Larcker Criterion, the square roots of AVE in each latent construct determine the discriminant validity, if this value is higher than the correlation values with all other latent constructs. Therefore, discriminant validity for all constructs have been established. These eight valid discriminant validity tests confirm that the measurement model of this study is reliable and acceptable (Table 4).

Table 5 - Latent Variable Correlations (Fornell-Larcker Criterion)

\begin{tabular}{|c|c|c|c|c|c|c|c|c|}
\hline Observed variable & Coordination & $\begin{array}{l}\text { Emotional } \\
\text { stability }\end{array}$ & Flexibilities & Listening & $\begin{array}{c}\text { Problems } \\
\text { Solving }\end{array}$ & $\begin{array}{c}\text { Questioning \& } \\
\text { Answering }\end{array}$ & $\begin{array}{c}\text { Assessing } \\
\text { person\&condition }\end{array}$ & Feedback \\
\hline Coordination & 0.781 & & & & & & & \\
\hline Emotional stability & 0.522 & 0.831 & & & & & & \\
\hline Flexibilities & 0.504 & 0.580 & 0.838 & & & & & \\
\hline Listening & 0.277 & 0.322 & 0.357 & 0.884 & & & & \\
\hline Problems Solving & 0.284 & 0.439 & 0.525 & 0.320 & 0.813 & & & \\
\hline $\begin{array}{l}\text { Questioning } \\
\text { \&Answering }\end{array}$ & 0.207 & 0.237 & 0.239 & 0.386 & 0.342 & 0.920 & & \\
\hline $\begin{array}{l}\text { Assessing person } \\
\text { \& Condition }\end{array}$ & 0.318 & 0.348 & 0.415 & 0.493 & 0.343 & 0.136 & 0.818 & \\
\hline Feedback & 0.334 & 0.416 & 0.550 & 0.398 & 0.573 & 0.253 & 0.537 & 0.793 \\
\hline
\end{tabular}

Source: Research data.

\section{Discussion and conclusion}

The purpose of the study was to identify and validate coaching skills in higher education. A faculty member can be a coach for both students and colleagues in the University of Medical Sciences and in the other University. Therefore, the study attempted to show which skills are the most important in higher education in Iran. Coaches act as a resource in educational organizations providing management and educational support. They try to improve activities and the performance of individuals with the general aim of enhancing individual and the organizations' achievements. According to Fraser et al. (2007), the role of a coach includes providing support to organizations, educational specialists, planning, professional developers, analyzers, factors of changes and they can 
also be supporters and providers of resources. Accordingly, coaching has multiple aspects, but the very heart of all those aspects and tasks is increasing the quality of individuals and their achievements. Individuals are considered coaches in universities when they enjoy special coaching skills. Thus, faculty members need such skills if they are to act as coaches. Coaching skills are not specifically mentioned and discussed in the literature, but rather sporadically they are mentioned here and there.

The result acknowledged that any person acting as a coach in the University of Medical Sciences and the other university should possess and manage at least eight skills. On the other hand, when selecting coaches eight criteria should be considered, as our study identified them as priorities; they are: Coordination, Listening, Questioning \& Answering, Feedback, Emotional Stability, Problem Solving, Assessing Person \& Condition, and Flexibility.

Therefore, the aim of the present study was to develop and validate a list of coaching skills. The results indicated that eigth skills were identified as main or priority coaching skills, and they were confirmed by experts of human resources development. The first coaching skill is Questioning \& Answering, seen as one of the priorities by experts in human resources. It shows that coaches who want to be more effective in their coaching domain should possess or learn this skill, through which individuals find out their strategies or weaknesses (WILSON; GISLASON, 2009).

The second skill is a feedback referring what occurs between the coaches and trainees after questioning and answering. Coaches who have the feedback skill can enjoy more effective relationships with their trainees, and this is good to improve activities and increase staff's motivation (PASSMORE, 2016). The third skill is coordination of information. It is important for a coach to effectively transfer information and knowledge to others. In the process of coaching, when transference of knowledge and information easily occurs, individuals with higher knowledge and awareness will improve their activities (WILSON; GISLASON, 2009).

Assessing Person \& Condition, Coordination, and Problem Solving are the other three skills. They are closely related to each other. Coaches who have the ability to assess their own trainees in terms of character and behavior and who know them better are more likely to have a positive impact on them. In addition, due to this identification, they can guide trainees with regard to their personality characteristics so that they can cooperate better and act more adequately in decision making. Coaches who have the ability of better Coordination and Problem Solving can naturally achieve more effective relationships with their trainees (COLLINS; CARSON; COLLINS, 2016). Coaches, aware of the process of problem solving and possessing such ability can be more successful in training their trainees.

Listening is another skill necessary for a coach as it makes their trainees understand the significance that coaches assign to them and their activities. In other words, when a coach sincerely listens to his or her trainees, he or she can assess their activities more appropriately. As a result, a coach can guide them more effectively (WILSON; GISLASON, 2009). Flexibility is, too, another coaching skill which can be a factor affecting creativity and innovation of coaches and trainers. Coaches who enjoy flexibility can make better and more rational decisions in a lot of situations and conditions. Flexibility affects other coaches assessment in such a way that it results in better assessments in different situations 
(CRAWFORD et al., 2017). Flexibility leads individuals to accept different ideas and beliefs and react more properly and effectively in different business environments. The last skill necessary for a coach is emotional stability, a reference to the ability of tolerating mental and psychological stresses in harsh working conditions (BUCHANAN; HUCZYNSKI, 2010). A coach who enjoys this skill can act better and more effectively in abnormal conditions. In other words, when a person is able to handle environmental stresses, he/she will likely make better decisions, assess conditions more appropriately, and establish more effective relationships with others.

\section{Research limitations and suggestions for further research}

Since the present study was conducted only in the mentioned universities in a developing country, other universities and professors from other countries and outside the academic realm, especially those working and researching in industries, could also be investigated for different or even better results. This type of research was conducted only on higher education systems and consequently does not cover basic education and schools. Therefore, it is recommended that a similar study be conducted in industrial organizations in order that other dimensions of coaching skills will be revealed. The present study should also be conducted in schools as it would greatly contribute to the personal development of school teachers.

\section{References}

AHANCHIAN, Ahmad; KARAMI, Alireza.; ABADI, Hosein. Modeling professional development of faculty members in higher education. Journal of Human Sciences Development, v. 5, n. 12, p. 16-31, 2014.

AL-AZAWEI, Ahmed; PARSLOW, Patrick; LUNDQVIST; Karsten. Barriers and opportunities of e-learning implementation in Iraq: a case of public universities. The International Review of Research in 0pen and Distributed Learning, v. 17, n. 5, p. 1-21, 2016. D0l: http://dx.doi.org/10.19173/irrodl.v17i5.2501.

AVERWEG, Udo Richard. Enabling role of an intranet to augment e-coaching. Industrial and Commercial Training, v. 42, n. 1, p. 47-52, 2010. D0l: https://doi.org/10.1108/00197851011013715.

BLACKMORE, Paul. Conceptions of development in higher education institutions. Studies in Higher Education, v. 34, n. 6, p. 663-676, 2009. D0l: http://dx.doi.org/10.1080/03075070902785598.

BLACKMORE, Paul; CASTLEY, Andrew. Capability development in universities. London: Leadership Foundation for Higher Education, 2006.

BRANCATO, Vera C. Professional development in higher education. New Directions for Adult and Continuing Education, n. 98, p. 59-65, 2003. D0I: http://dx.doi.org/10.1002/ace.100.

BUCHANAN, David; HUCZYNSKI, Andrzej. Organizational behaviour. London: Pearson, 2010. 
BYHAM, William C.; MOYER, Reed P. Using competencies to build a successful organization. [s. L.: s. n.], 2005. A monograph of Development Dimensions International. Retrieved June 20, 2008.

CAMPBELL, Patricia F.; MALKUS, Nathaniel N. The impact of elementary mathematics coaches on student achievement. The Elementary School Journal, v. 111, n. 3, p. 430-454, 2011. D0I: https:// doi.org/10.1086/657654.

COLLINS, Loel, CARSON, Howie J.; COLLINS, Dave. Metacognition and professional judgment and decision making in coaching: importance, application and evaluation. International Sport Coaching Journal, v. 3, n. 3, p. 355-361, 2016. D0l: https://doi.org/10.1123/iscj.2016-0037.

CRAWFORD, April D. et al. Integrating professional development content and formative assessment with the coaching process: the Texas school ready model. Theory Into Practice, v. 56, n. 1, p. 56-65, 2017. DOl: http://dx.doi.org/10.1080/00405841.2016.1241945.

FARRELL, Andrew Mark; RUDD, John M. Factor analysis and discriminant validity: a brief review of some practical issues. Anzmac, 2009.

FORNELL, Claes; LARCKER, David F. Evaluating structural equation models with unobservable variable and measurement error. Journal of marketing research, 39-50, 1981.

FRASER, Christine et al. Teachers' continuing professional development: contested concepts, understandings and models. Journal of In-Service Education, v. 33, n. 2, p. 153-169, 2007. D0I: http:// dx.doi.org/10.1080/13674580701292913.

FRAZEE, Rebecca Vaughan. E-coaching in organizations: a study of features, practices, and determinants of use. 2008. (Ph.D. thesis) - University of San Diego, San Diego, 2008. Available in: <https://www. learntechlib.org/p/127682/>. Access in: 2017.

FULLAN, Michael; KNIGHT, Jim. Coaches as system leaders. Educational Leadership, v. 69, n. 2, p. 50-53, 2011.

HEJAZI, Mohammad.; ROSTAMI, Farzad. Investigation professional development of faculty members: case study (Beheshti University). Journal of Educational Leadership, v. 6, n. 3, p. 43-59, 2010.

HOUSTON, James A. Coaching for change: amount of instructional coaching support to transfer science inquiry skills from professional development to classroom practice. 2015. (Thesis) - University of NebraskaLincoln, Nebraska, 2015. Available in: <http://digitalcommons.unl.edu/cehsedaddiss/223/>. Access in: 2017.

HOWLEY, Aimee Anton et al. The development of a valid and reliable instrument for measuring instructional coaching skills. Professional Development in Education, v. 40, n. 5, p. 779-801, 2014. D0I: http://dx.doi.or g/10.1080/19415257.2014.919342.

HULLAND, John. Use of partial least squares (PLS) in strategic management research: a review of four recent studies. Strategic management journal, 20(2), 195-204, 1999. 
HUR, Mann Hyung; IM, Yeonwook. The influence of e-learning on individual and collective empowerment in the public sector: an empirical study of Korean government employees. The International Review of Research in Open and Distributed Learning, v. 14, n. 4, 2013. D0l: http://dx.doi.org/10.19173/irrodl.v14i4.1498.

IVES, Yossi. What is 'coaching'? An exploration of conflicting paradigms. International Journal of Evidence Based Coaching and Mentoring, v. 6, n. 2, p. 100-113, 2008.

JONES, Rebecca J.; WOODS, Stephen Anthony; GUILLAUME, Yves R. F. The effectiveness of workplace coaching: a meta-analysis of learning and performance outcomes from coaching. Journal of Occupational and Organizational Psychology, v. 89, n. 2, p. 249-277, 2016.

KAISER, Henry F. The varimax criterion for analytic rotation in factor analysis. Psychometrika, 23(3), 187200, 1958.

KARIMI, Hossein et al. Review the problems of the upgrade process: faculty members. Journal of Medical Development Training, v. 8, n. 18, p. 73-85, 2015. Available in: <http://www.magiran.com/viewpdf. asp?no=1>. Access in: Sep. 2017.

KING, Patricia M. Principles of development and developmental change underlying theories of cognitive and moral development. Journal of College Student Development, v. 50, n. 6, p. 597-620, 2009. D0I: http:// dx.doi.org/10.1353/csd.0.0104.

KLENOWSKI, Val; ASKEW, Sue; CARNELL, Eileen. Portfolios for learning, assessment and professional development in higher education. Assessment \& Evaluation in Higher Education, v. 31, n. 3, p. 267-286, 2006. DOl: http://dx.doi.org/10.1080/02602930500352816.

KOWAL, Julie; STEINER, Lucy. Instructional coaching. Issue Brief, Sep. 2007. Center for Comprehensive School Reform and Improvement. Available in: <http://www.centerforcsri.org>. Access in: 2017.

MARSH, Juliy A.; SLOAN MCCOMBS, Jennifer; MARTORELL, Francisco. How instructional coaches support data-driven decision making: policy implementation and effects in Florida middle schools. Educational Policy, v. 24, n. 6, p. 872-907, 2010. DOl: http://dx.doi.org/10.1177/0895904809341467.

MCALEESE, Ray. STAFF development in higher education 1961-78: part I. British Journal of Teacher Education, v. 5, n. 2, p. 107-132, 1979. D0l: http://dx.doi.org/10.1080/0260747790050201.

MCLEAN, Gary N. et al. Development and initial validation of an instrument measuring managerial coaching skill. Human Resource Development Quarterly, v. 16, n. 2, p. 157-178, 2005. DOl: http://dx.doi.org/10.1002/ hrdq.1131.

NICHOLLS, Gill. Professional development in higher education: new dimensions and directions. London: Routledge, 2014.

NOURSHAHI, H; SAMIEI, L. Influence in-service on professional development in higher education. Journal of Higher Education, v. 9, n. 13, p. 67-81, 2011. 
OTHMAN, Norasmah; YEE, Chia Swee. Empowering teaching, learning, and supervision through coaching in action research. Journal of Management Research, v. 7, n. 2, p. 98-108, 2015. D0l: http://dx.doi. org/10.5296/jmr.v7i2.6931.

PASSMORE, Jonathan. Coaching psychology: applied practice in safety critical environments. In: GRANT. Pauline (Ed.). Business psychology in cction: creating flourishing organisations through evidenced based and emerging practice. Leicestershire: Matador, 2016. p. 1-14.

PEDHAZUR, Elazar J., SCHMELKIN, Liora Pedhazur. Measurement, design, and analysis? An integrated pproach. Psychology Press, 2013.

POLLY, Drew; MRAZ, Maryann; ALGOZZINE, Robert. Implications for developing and researching elementary school mathematics coaches. School Science and Mathematics, v. 113, n. 6, p. 297-307, 2013. D0l: http:// dx.doi.org/10.1111/ssm.12029.

RABIEE, Ali; NAZARIAN, Zahra; GHARIBSHAEYAN, Raziyeh. An explanation for internet use obstacles concerning e-learning in Iran. The International Review of Research in Open and Distributed Learning, v. 14, n. 3, p. 361-376, 2013. D0l: http://dx.doi.org/10.19173/irrodl.v14i3.1412.

REINBOTH, Michael; DUDA, Joan L; NTOUMANIS, Nikos. Dimensions of coaching behavior, need satisfaction, and the psychological and physical welfare of young athletes. Motivation and Emotion, v. 28, n. 3, p. 297313, 2004. D0l: http://dx.doi.org/10.1023/B:MOEM.0000040156.81924.b8.

RIENTIES, Bart; BROUWER, Natasa; LYGO-BAKER, Simon. The effects of online professional development on higher education teachers' beliefs and intentions towards learning facilitation and technology. Teaching and Teacher Education, v. 29, p. 122-131, 2013. D0I: https://doi.org/10.1016/j.tate.2012.09.002.

ROSSETT, Allison; MARINO, Gerald. If coaching is good, then e-coaching is. T and D, v. 59, n. 11, p. 46, 2005.

ROXÅ, Torgny; MÅRTENSSON, Katarina. Strategic educational development: a national Swedish initiative to support change in higher education. Higher Education Research \& Development, v. 27, n. 2, p. 155-168, 2008. DOl: http://dx.doi.org/10.1080/07294360701805291.

SCHROEDER, Jan; FRIESEN, Karlie. Growth potential continues for personal training: 2007 IDEA personal training programs \& equipment survey data show that personal trainers are creative, specialized and poised for new opportunities. IDEA Fitness Journal, v. 4, n. 8, p. S1-S1, 2007.

THOMPSON, Bruce. Exploratory and confirmatory factor analysis: understanding concepts and applications. Washington, DC: American Psychological Association, 2004.

WHITTEN, Donna L. Mentoring and work wngagement for female accounting, faculty members in higher education. Mentoring \& Tutoring: Partnership in Learning, v. 24, n. 5, p. 365-382, 2016. D0l: http://dx.doi. org/10.1080/13611267.2016.1275391. 
WILSON, Judith; GISLASON, Michelle. Coaching skills for nonprofit managers and leaders: developing people to achieve your mission. New Jersey: John Wiley \& Sons, 2009.

Received on September 18th, 2017. Approved on November 27th, 2017.

Mohammad Mohammadisadr is MA in Educational Administration at University of Isfahan in Iran (2012). He is PhD student of Educational Administration, Faculty of Educational Sciences and Psychology, University of Isfahan. Iran. He has published articles in the fields of Professional Development and Organizational Improvement.

Seyed Ali Siadat graduated in MA Business Management of Texas South University in 1979. He is PhD in Educational Administration at Texas University of Houston in 1989, United State of America. He is a Professor of the Faculty of Educational Sciences and Psychology, University of Isfahan, Iran. He published many books and articles in the Field of Educational Management and has expertise in Educational Economy and Organizational Development. He graduated in Economy at the National University of Iran in 1975.

Reza Hoveida got $\mathrm{PhD}$ in Educational Administration in the University of Isfahan//ran. He is an Associate professor at the Faculty of Educational Sciences and Psychology. University of Isfahan, Iran. 